\title{
Apatite as a tracer for magmatic-hydrothermal ore-forming processes
}

\author{
S. Karvinen*, A. Heinonen and C. Beier \\ University of Helsinki \\ *Corresponding author e-mail: seppo.karvinen@helsinki.fi
}

\begin{abstract}
Summary This project focuses on the trace element chemistry of igneous apatite in various magmatic systems with the use of in situ analytical techniques. The composition of apatite may possibly be used as a tracer for various magmatic-hydrothermal processes due to the breadth of chemical substitutions possible within the structure. Apatite is found in many mineralized layered intrusions as a minor phase. Apatite may be utilized in the tracking of metasomatic fluids in layered intrusions or in geochronological studies in the absence of other commonly used phases i.e. zircon. Apatite accumulations can be exploited economically for phosphorus and possibly for rare earth elements as well.
\end{abstract}

\section{Introduction and background to current research}

This contribution outlines a $\mathrm{PhD}$ project that investigates the trace element chemistry of igneous apatite. The project comprises three subprojects, each of which concentrates on a different type of magmatic system: 1) carbonatites, 2) massif-type anorthosites and layered intrusions, and 3) rapakivi granites. The aim of the study is to gain new insight into the substitution mechanisms of trace elements in these chemically different magmatic environments and to compile a chemical database of apatite compositions. The main analytical methods utilized are electron microprobe (EPMA) and laser ablation inductively coupled plasma mass spectrometer (LAICP-MS) aided with cathodoluminescence (CL) and scanning electron microscopy (SEM) imaging techniques. These in situ methods allow the quantification of compositional differences (e.g. growth zonation, alteration) between and within individual grains of apatite in a single sample. The current stage of the project concentrates on the carbonatite subproject, in which the apatite compositions of the Archean Siilinjärvi glimmerite-carbonatite rocks are being studied. The sub-project on layered intrusions and massif-type anorthosites is planned to be launched during 2021.

\section{Research questions at hand}

The apparent compositional variability and geological ubiquity makes apatite a potential versatile tracer of numerous geochemical processes. Calcium-phosphate apatite minerals $\left[\mathrm{Ca}_{10}\left(\mathrm{PO}_{4}\right)_{6}(\mathrm{~F}, \mathrm{OH}, \mathrm{Cl})_{2}\right]$ are the most common phosphate minerals in the Earth's crust and present as accessory or trace phases in most magmatic, metamorphic, and sedimentary rocks (e.g. Piccoli and Candela 2002, Hughes and Rakovan 2015). Magmatic apatite is typically fluorapatite in composition, with a varying hydroxyl component (Piccoli and Candela 2002). Chlorapatite is found in some mafic-ultramafic intrusions (e.g. Boudreau et al. 1986, discussed below) and in metasomatically altered rocks (Kusebauch et al. 2015). Bromine, I, S, C, and structural water can also be incorporated into the apatite structure to some extent. Sulphur is compatible in the apatite structure in many oxidation states ranging from reduced $\left(\mathrm{S}^{2-}\right)$ to oxidized $\left(\mathrm{S}^{4+}\right)$ (Konecke et al. 2017). The $\mathrm{S}^{6+} / \Sigma \mathrm{S}$ ratio can be used as an oxybarometer (Konecke et al. 2019).

The apatite structure can incorporate a range of elements to cation and anion sites, often with coupled substitutions to balance charges (Pan and Fleet 2002). Trace elements, such as 
rare earth elements (REE) are strongly partitioned into apatite, with a preference of middle REE over heavy REE (e.g. Hughes et al. 1991, Pan and Fleet 2002). This enrichment in REE may lead to apatite accumulations being a potential source for REE (Emsbo et al. 2015). Economic apatite accumulations are typically exploited as raw material for phosphate fertilizers, with phosphorites (chemical sediments, Filippeli 2008) being the most voluminous rock type. Magmatic deposits are also exploited e.g. the Siilinjärvi glimmerite-carbonatite complex (O'Brien et al. 2015), which may be potentially be utilized for REE as well (Decrée et al. 2020). Besides alkali rock types and carbonatites, iron-oxide-apatite cumulates (Kiruna-type, nelsonites or oxide-apatite-gabbronorites) are also exploited.

\section{Future prospects}

\subsection{Chlorapatite in layered intrusions}

Chlorine-bearing apatite is present in or near platinum group element (PGE) mineralized strata in many layered mafic-ultramafic intrusions, (e.g. Bushveld; JM and Merensky Reef; Boudreau, 1993; Great Dyke; Boudreau et al., 1986; Munni Munni; Boudreau et al., 1993; Stillwater; Boudreau and McCallum, 1989; Penikat; Halkoaho, 1994; Näränkävaara, Järvinen et al., 2020; Duluth Complex; Bathtub Intrusion; Raič et al., 2018; Norilsk; Serova and Spiridonov, 2018). The role of chlorine-bearing fluids in the metallogenesis of PGE reefs is controversial (cf. Godel 2015 and references therein). There are proponents of both orthomagmatic (Campbell et al. 1983) and magmatic-hydrothermal genetic models (Boudreau et al. 1986). Apatite compositions, textures, and inclusions (monazite, xenotime) can provide evidence of metasomatic events and the type of metasomatic fluid(s) involved in them (Harlov et al. 2002, Harlov and Förster 2003).

\subsection{Apatite geochronology}

Apatite can also be used in geochronological studies as uranium and thorium can be incorporated into the structure (Chew et al. 2011). Another suitable method for dating of maficultramafic intrusions is the ${ }^{176} \mathrm{Lu}-{ }^{176} \mathrm{Hf}$ isotope system (Chew and Spikings 2015, Scoates and Wall 2015). Apatite is a suitable mineral for this as well because $\mathrm{Lu}$ is readily incorporated $(\mathrm{Kd}$ $>>1)$ into the apatite structure whereas $\mathrm{Hf}$ is not $(\mathrm{Kd}<1)$.

\subsection{Fennoscandian Fe-Ti(-V)-P mafic-ultramafic intrusions}

In Finland, there are Paleoproterozoic $(\sim 1.88 \mathrm{Ga}) \mathrm{Fe}-\mathrm{Ti}(-\mathrm{V})-\mathrm{P}$ enriched mafic intrusions. These intrusions are typically composed of more fractionated mafic rocks than the $\mathrm{Ni}-\mathrm{Cu}$ mineralized mafic-ultramafic Vammala and Kotalahti type intrusions of similar age (e.g. Makkonen 2017). These Fe-Ti(-V)-P intrusions are located within but near the periphery of the Central Finland Granitoid Complex, situated into two major areas with several small, gabbroic intrusions Kauhajärvi (Kärkkäinen and Appleqvist 1999) and Koivusaarenneva (Kärkkäinen and Bornhorst 2003). The Kauhajärvi intrusion hosts Fe-Ti oxide (magnetite, ilmenite) and apatite rich layers which vary in thickness from 2 to 30 meters. The Koivusaarenneva gabbro has ilmenite and vanadiniferous magnetite layers (Kärkkäinen and Bornhorst 2003). The composition of apatite in these localities has not been investigated in detail. The trace element and halogen concentrations could possibly provide additional information about the conditions in which the mineralizations formed.

\section{Acknowledgements}

This PhD project is funded by the K.H. Renlund foundation. Mr. Mikko Savolainen (Yara Suomi Oy) is thanked for providing the Siilinjärvi glimmerite-carbonatite samples. 


\section{References:}

Boudreau, A. E (1993) Chlorine as an exploration guide for the platinum-group elements in layered intrusions. J Geochemical Exploration, 48: 21-37.

Boudreau, A. E., Mathez, E. A., McCallum, I. S (1986) Halogen geochemistry of the Stillwater and Bushveld Complexes: evidence for transport of the platinum-group elements by Cl-rich fluids. J Petrol 27: 967-986.

Boudreau, A. E., Love, C., Hoatson, D. M (1993) Variation in the composition of apatite in the Munni Munni Complex and associated intrusions of the West Pilbara Block, Western Australia. Geochim. Cosmochim. Acta 57: 4467-4477.

Chew, D. M., Sylvester, P. J., Tubrett, M. N (2011) U-Pb and Th-Pb dating of apatite by LA-ICPMS. Chem. Geol 280: 200-216.

Chew, D. M., Spikings, R. A (2015) Geochronology and thermochronology using apatite: time and temperature, lower crust to surface. Elements 11: 189-194.

Decrée, S., Savolainen, M., Mercadier, J., Debaille, V., Höhn, S., Frimmel, H., Baele, J. M (2020) Geochemical and spectroscopic investigation of apatite in the Siilinjärvi carbonatite complex: Keys to understanding apatite forming processes and assessing potential for rare earth elements. Ap. Geochem 123: 104778.

Emsbo, P., McLaughlin, P. I., Breit, G. N., du Bray, E. A., Koenig, A. E (2015) Rare earth elements in sedimentary phosphate deposits: solution to the global REE crisis? Gondwana Research 27: 776-785.

Filippelli, G. M (2008) The global phosphorus cycle: past, present, and future. Elements 4: 89-95.

Godel, B (2015) Platinum-group element deposits in layered intrusions: recent advances in the understanding of the ore forming processes. In: Charlier B., Namur O., Latypov R., Tegner C. (eds) Layered intrusions. Springer Geology, Dordrecht, pp. 379-432.

Halkoaho, T. (1994) The Sompujärvi and Ala-Penikka PGE reefs in the Penikat layered intrusion, northern Finland. Doctoral dissertation. Acta Universitatis Ouluensis: Series A, Scientiae rerum naturalium.

Harlov, D. E., Förster, H. J., Nijland, T. G (2002) Fluid-induced nucleation of (Y+ REE)-phosphate minerals within apatite: Nature and experiment. Part I. Chlorapatite. Am Mineral 87: 245-261.

Harlov, D. E., Förster, H. J (2003) Fluid-induced nucleation of (Y+ REE)-phosphate minerals within apatite: Nature and experiment. Part II. Fluorapatite. Am Mineral 88: 1209-1229.

Hughes JM, Cameron M, Mariano AN (1991) Rare-earth-element ordering and structural variations in natural rareearth-bearing apatites. Am Mineral 76: 1165-1173

Hughes JM, Rakovan JF (2015) Structurally robust, chemically diverse: apatite and apatite supergroup minerals. Elements 11: 165-170

Konecke B. A., Fiege A., Simon A. C., Parat F. and Stechern A.(2017a) Co-variability of $\mathrm{S}^{6+}$, $\mathrm{S}^{4+}$, and $\mathrm{S}^{2-}$ in apatite as a function of oxidation state: implications for a new oxybarometer. Am Mineral 102: 548-557.

Konecke, B. A., Fiege, A., Simon, A. C., Linsler, S., Holtz, F (2019) An experimental calibration of a sulfur-inapatite oxybarometer for mafic systems. Geochim. Cosmochim. Acta 265: 242-258.

Kusebauch, C., John, T., Whitehouse, M. J., Engvik, A.K (2015) Apatite as probe for the halogen composition of metamorphic fluids (Bamble Sector, SE Norway). Contrib Mineral Petrol: 170, 1-20.

Kärkkäinen, N., Appelqvist, H (1999) Genesis of a low-grade apatite-ilmenite-magnetite deposit in the Kauhajärvi gabbro, western Finland. Miner Deposita 34: 754-769.

Kärkkäinen, N. K., Bornhorst, T. J (2003) The Svecofennian gabbro-hosted Koivusaarenneva magmatic ilmenite deposit, Kälviä, Finland. Miner Deposita 38: 169-184.

Järvinen, V., Halkoaho, T., Konnunaho, J., Heinonen, J. S., \& Rämö, O. T. (2020). Parental magma, magmatic stratigraphy, and reef-type PGE enrichment of the 2.44-Ga mafic-ultramafic Näränkävaara layered intrusion, Northern Finland. Miner Deposita 55: 1535-1560.

Makkonen, H. V., Halkoaho, T., Konnunaho, J., Rasilainen, K., Kontinen, A., Eilu, P (2017) Ni-(Cu-PGE) deposits in Finland-geology and exploration potential. Ore Geol. Rev 90: 667-696.

O'Brien, H., Heilimo, E., Heino, P (2015) The Archean Siilinjärvi carbonatite complex. In Mineral deposits of Finland. Elsevier, pp. 327-343.

Parat, F., Holtz, F (2004) Sulfur partitioning between apatite and melt and effect of sulfur on apatite solubility at oxidizing conditions. Contributions to Mineralogy and Petrology 147: 201-212.

Piccoli, P.M., Candela, P.A (2002) Apatite in igneous systems. Rev Mineral Geochem 48: 255-292.

Raič, S., Mogessie, A., Krenn, K., Hauzenberger, C.A., Tropper, P (2018) Deciphering Magmatic and Metasomatic Processes Recorded by Fluid Inclusions and Apatite within the $\mathrm{Cu}-\mathrm{Ni} \pm$ PGE-Sulfide Mineralized Bathtub Intrusion of the Duluth Complex, NE Minnesota, USA. J Petrol 59: 1167-1192.

Scoates J., Wall C (2015) Geochronology of Layered Intrusions. In: Charlier B., Namur O., Latypov R., Tegner C. (eds) Layered intrusions. Springer Geology, Dordrecht, pp. 3-74.

Serova, A. A., Spiridonov, E. M (2018). Three types of apatite in Norilsk sulfide ores. Geochemistry International 56: 474-483. 